\title{
Study Loan Defaults Among Tertiary Graduates
}

\author{
Nor Balkish Zakaria ${ }^{1}$, Muhammad Rasyid ${ }^{2}$, Norazida Mohamed ${ }^{3}$, Dalila Daud ${ }^{4}$ \& Aida Maria Ismail ${ }^{5}$ \\ ${ }^{1}$ Faculty of Accounting, Universiti Teknologi MARA, Cawangan Johor, Kampus Segamat, Malaysia \\ ${ }^{2}$ Department of Management, Universitas Lancang Kuning, Indonesia \\ ${ }^{3}$ Accounting Research Institute, Universiti Teknologi MARA, Shah Alam, Selangor, Malaysia \\ ${ }^{4}$ Faculty of Accounting, Universiti Teknologi MARA, Cawangan Negeri Sembilan, Seremban 3, Malaysia \\ ${ }^{5}$ Faculty of Accounting, Universiti Teknologi MARA, Cawangan Selangor, Bandar Puncak Alam, Selangor, \\ Malaysia \\ Correspondence: Nor Balkish Zakaria, Faculty of Accounting, Universiti Teknologi MARA, Cawangan Johor, \\ Kampus Segamat, Malaysia. E-mail: norbalkish@uitm.edu.my
}

Received: May 12, 2020

doi:10.5430/ijfr.v11n3p125
Accepted: June 20, 2020

Online Published: June 29, 2020

URL: https://doi.org/10.5430/ijfr.v11n3p125

\begin{abstract}
Educational Loan is an alternative of financial aids that is provided by the study funding agencies of Malaysia to reduce the economic burden of students in order to finance their studies at tertiary education level. Despite the increasing number of students who obtaining these educational loans, the issue of default in loan repayment among borrowers merely needs research attention. Thus this study aims to investigate the factors of study loan default among Malaysia tertiary graduates. Among the factors examined are family income, employment status and loan amount while respondents' age, gender, marital status and education level are controlled. Questionnaires were distributed to 430 Universiti Teknologi MARA, Johor, Malaysia graduated respondents via online and 209 were returned The result of this study revealed that the employment status, loan amount and education level are significant to study loan default among Malaysian tertiary graduates. The results could serve some highlights to any study financing agencies to further understand their borrower intuitions in paying back loans they owed.
\end{abstract}

Keywords: study loan, loan default, tertiary graduates

\section{Introduction}

University is an authorised and noble institution of higher learning that provides facilities for teaching-learning; and undertaking research to grant academic degrees which comprise either graduate or professional schools which may confer master's degrees and doctorates.

Malaysian higher education system has grown rapidly and become stronger for the past decade. In the past ten years, the increasing numbers of student enrolments in both public and private institutions indicate that the trend is growing year by year (Zainal and Ismail, 2017).

As one of the growing regional and international learning hubs in Asia, Malaysia has also gained an increasingly popular choice for international students, and has set an ambitious goal of attracting 250000 international students by 2025. Malaysian Ministry of Education in 2017 stated that 11,925 undergraduates and 21,170 postgraduates are foreigner students in local public universities; while 92,083 for undergraduates and 11,115 postgraduates were recorded in local private universities. In addition, multiracial Malaysia serves higher education needs for every Malay, Chinese, Indian and many more. This factor become the most attraction of international students to choose in pursuing their studies especially from China, Singapore, Thailand, Indonesia, Pakistan, Sri Lanka, Yaman, Libya, Sudan, India, Bangladesh, Kazakhstan and Nigeria.

The increase in the number of student and tertiary education institutions has resulted in a shortage of scholarship that is available for the students. The scholarships are offered to not only citizens of Malaysia but also reachable to other nations depends on the scholar schemes. Hence, with the outstanding numbers of students in both public and private Malaysian universities, the challenge to grab scholarship has become so competitive. This has then created an attention to government and other institutions to help these tertiary students to fund their study and survival needs.

Despite of the number of scholarships offered, the criteria to apply is still tough and very selective differ from one field to another (Sugiyarti, Jasmi, Basiron, Huda, Shankar, and Maseleno, 2018). Thus, unsuccessful applicants have to find 
alternatives to keep pursuing their study. This financial assistance becomes essential for students who wish to pursue their studies (Bakar, Masud and Jusoh, 2006). The sources of tertiary education financing in Malaysia consists of government and private agencies. The considerations given by these tertiary education funders are lower interest rates and flexible repayment period upon negations. Many banking institution and conglomerates offer funding for higher education to students whether in terms of loans or scholarships such as Bank Rakyat, SHELL, Khazanah, Petronas, Maybank, CIMB Bank and many more. However, the competition to secure either partial loan or scholarships from these institutions and conglomerates are very stiff.

Hence, the National Higher Education Fund (also known as Perbadanan Tabung Pendidikan Tinggi Nasional, PTPTN) emerge in 1997 to provide education loans to students pursuing their studies at local education institutions. This loan will enable students to fully or partially pay their fees and their subsistence for the duration of their study. National Higher Education Fund (PTPTN) had disbursed loans to 2.17 million students, totalling more than RM50.41 billion as reported by New Straits Times in 2017.

Despite of the Malaysian government and its agencies effort to fund these tertiary students, many students still tend to take it for granted by defaulting in their study loan repayment. As the numbers of borrowers increase, the repayment of the amount borrowed is much lower than expected (Wong, Nasharuddin and Ismail, 2015).

Study loan default would not be a problem to these agencies if the borrower repay the loan promptly. Some prior researches engaged vector machine to predict loan repayment failure that has its own practical potential in credit prediction (Qian and $\mathrm{Hu}, 2019$ ) while $\mathrm{Li}$ and Chen (2019) combined logistic regression algorithm and artificial neural network model to improve the prediction on credit facility management.

However, students' loans repayment remains an unresolved issue. According to PTPTN 2019 report, the repayment of PTPTN loan has decreased and only RM817.56 million has been collected in 2018 compared to RM1.324 billion in 2017.

Hence, there are still much left to be explored on the issue of whether the borrower is capable to repay their study loan. Does amount borrowed affect the borrowers to default in loan payments? Do income, education or other borrowers' personal traits influence the default on loan repayment? What are other influencing factors for these graduated students to default in their study loan repayment?

Thus, this research aims to study the factors that caused default in study loan repayment and the perception of public towards default in study loan payments. A well-structured questionnaire is used to collect the data and explain the findings of this study. Some of the issues of default in repayment were identified that triggered the worrisome of the National Higher Education Fund (PTPTN). The utmost finding of the factors of study loan default among graduates could benefit the loan provider as to minimize the default in payment.

The remainder of this paper is organized as follows. Section 2 discusses the underpinning theory that governs this study hypotheses supported by the review of previous studies on study loan default in Malaysia. Section 3 presents the research methodology, followed by Section 4 that discusses on the findings of the empirical results. Finally Section 5 concludes the paper.

\section{Literature Review and Hypothesis Development}

\subsection{Theory of Reasoned Action (TRA)}

TRA is a model for the forecast of behavioural intention, spanning predictions of attitude and predictions of behaviour. The subsequence separation of behavioural intention from behaviour allows for clarification of limiting factors on attitudinal influence (Martin, James, Andrew, Icek and Loken, 1980). Martin et al. (1980) established a model that led to the study of attitude and behaviour. This research applies the TRA model in order to examine the process that indicates the decision of whether or not to repay certain loan. The TRA states that the direct forerunner of the decision is loan repayment intention. This will later interpret as to actual behaviour of repayment of loan depending on the degree of the student's evaluation that perceives it as negative or positive.

\subsection{Study Loan and Repayment}

Besides PTPTN loan, students also rely on other funding alternatives to pursue their studies in higher education institute that are mostly offered by banking institutions or private agencies in terms of loan or scholarships. Maybank for example in 2018 has disbursed RM27 million in scholarships to students. As at December 2018, CIMB Bank has disbursed RM10.6 million to 16 scholars to pursue undergraduate studies in reputable study institutions worldwide. Sustainability Report of Petronas 2018 shows that more than 36,000 students globally gained funding from the PETRONAS Education Sponsorship Programme (PESP), of which 387 students were awarded sponsorships in 2018 where $45 \%$ are international universities and $55 \%$ from Malaysian universities. 
As early as the mid-1970s, the emphasis in higher education policy began to shift from grants to loans as the means for providing financial assistance to low and moderate income families for further tertiary education in universities (Gross, Cekic, Hossler, and Hillman, 2010). Hence, educational loan become the main source of financing for students to pursue their tertiary education.

Steiner and Barone (2014) examined the student loan default at individual-level which correlate to student loan default. Demographic and family background factors were tested to the default in study loan repayment. Borrowers who report a smaller Adjusted Gross Income (parental income for dependent students) on the Free Application for Federal Student Aid (FAFSA) are more likely to default on student loans (Kofoed, 2017). McKinney, Gross and Inge (2014) suggested that one of the reasons borrowing of educational loan has increased is due to the increase in educational costs.

Hence, students' family background is important as their financial support to face the challenge postgraduates. Healthy family could provide any needs without the borrowers struggle to repay the loan. Thus,

H1: Family income is significant to study loan default

Insufficient fund lead to high cost of living where borrowers have not enough money to support the cost. In that case, borrowers have to skip the repayment for two, three times or more. A delayed instalment is also said to be delinquent and a repayment that has not been made (Redd, 2001). According to Lochner and Monge-Naranjo (2004), students who are successful in studies tend to have lower loan default rates than those who are not since the excel students could be offered good jobs easier. Moreover, majority of failure students who did not complete their studies were found to default in their study loan repayment (Woo, 2002).

McMilion (2004) found out that unemployment is the main factor that lead to study loan default upon leaving universities. Post-college characteristics are those that occur after a borrower has left school and include education (i.e. income, highest degree earned, and indebtedness), marital status and number of dependents. Those with high earnings after they leave study life are less likely to default than those with low earnings. Borrowers' instability income that do part-time jobs or do not have a permanent job are those who are prone to default in study loan payment (Hoynes, Miller and Schaller, 2012).

Hence, whether one is employed may influence default of study loan. In addition, if he or she is employed, is it temporary or fix in contract? Such question may add to the loan default factors. Thus, this study hypothesis that,

H2: Employment status is significant to factors of loan default

The amount of loan borrowed also play important roles to determine the repayment ability as these borrowers are merely young adults who just leave universities and newly started their career.

Woo (2002) found that high loan limits affect the loan repayment as it served greater burden to these students 'life post-varsities. Hillman (2015) stated that most of the students concern about the amount of debt that they are carrying into life after college and are worried about their ability to repay the debt based on income.

When the amount borrowed increase, the students will be in more debt. Hence, the amount borrowed by students may influence the factors of loan default. Thus, this study develop the final hypothesis as,

H3: Loan amount is significant to study loan default

\section{Methodology}

This study examines the family income, employment status and loan amount borrowed of study loan towards the factors of study loan default. This study parameter also controls the effect of graduates' age, gender, marital status and educational level.

For the purpose of this study, 430 questionnaires were randomly distributed to Universiti Teknologi MARA graduated respondents through online questionnaire. Universiti Teknologi MARA was chosen since it is the biggest university with the highest number of students in Malaysia across various academic courses. However, only Universiti Teknologi MARA Johor branch was selected to carry out this study due to geographical alumni data factor available and research time constraint. A final of 209 questionnaires were returned and filled. Categorical scores are used to guide respondents' answer.

\section{Result and Findings}

\subsection{Descriptive Results}

Table 1 presents the results of the whole parameter respondents. For family income, majority of the respondents (more than 90\%) came from low to medium income earners. Thus, these respondents depend on the study loan during their study period. Almost half of the respondents (49.4\%) are currently working, some are steady in job while some are just getting their job in less than 6 months. 
More than three quarter of the respondents' loan amount are below RM50,000. Majority of the respondents are between 22-25 years old implying that these young respondents were just few years leaving universities. Male and female respondents' percentages are more or less equal. Most of them are still single (41.15\%), followed by married with no child status (30.6\%). This implies that the respondents have no high responsibility towards family commitment. Finally, Table 1 also shows that most of the respondents have graduated with Diploma (36.8\%) and Bachelor Degree $31.1 \%$ ) while others are certificate holders and post graduates. Almost half of respondents (42\%) highly defaulted their study loan repayments more than three times a year; $34 \%$ defaulted less than three times a year while the remaining mark a tendency to default.

Table 1. Respondents' descriptive results, N=209

\begin{tabular}{|c|c|c|c|}
\hline & Details & No & $\%$ \\
\hline \multirow{5}{*}{ Family Income } & 1-low $(<1.9 \mathrm{k})$ & 47 & 22.5 \\
\hline & 2-low medium (2-4.9k) & 93 & 44.5 \\
\hline & 3-medium (5-9.9k) & 54 & 25.8 \\
\hline & 4-high (10-19.9k) & 11 & 5.26 \\
\hline & 5 -very high $(.20 \mathrm{k})$ & 4 & 1.94 \\
\hline \multirow{6}{*}{ Employment } & 1-not working & 46 & 22 \\
\hline & 2- applying job & 29 & 13.8 \\
\hline & 3- part time job & 31 & 14.8 \\
\hline & 4-working $<6$ months & 61 & 29.2 \\
\hline & 5- steady working & 42 & 20.2 \\
\hline & $>6$ months & & \\
\hline \multirow{5}{*}{ Loan Amount } & 1-RM5-14.9K & 52 & 25.8 \\
\hline & 2-RM15-29.9K & 70 & 33.5 \\
\hline & 3-RM30-44.9K & 63 & 30.1 \\
\hline & 4-RM45-59.9K & 24 & 11.5 \\
\hline & 5-More than RM60K & 0 & 0 \\
\hline \multirow{3}{*}{ Age } & $18-22$ & 69 & 33 \\
\hline & $22-25$ & 97 & 46.4 \\
\hline & 25 above & 43 & 20.6 \\
\hline \multirow{2}{*}{ Gender } & 1-male & 91 & 43.54 \\
\hline & 2-female & 118 & 56.46 \\
\hline \multirow{5}{*}{ Marital Status } & 1-married with no child & 64 & 30.6 \\
\hline & 2-married with 3 children & 51 & 24.4 \\
\hline & 3-married with $>3$ children & 5 & 2.39 \\
\hline & 4-single & 86 & 41.15 \\
\hline & 5-divorcee & 3 & 1.44 \\
\hline \multirow{5}{*}{ Education } & 1-TVET/Certification & 62 & 29.7 \\
\hline & 2-Diploma & 77 & 36.8 \\
\hline & 3-Bachelor Degree & 65 & 31.1 \\
\hline & 4-Master Degree & 4 & 13.8 \\
\hline & 5-Phd & 1 & 0.5 \\
\hline \multirow{4}{*}{ Loan Default } & 1-Tend to default & 49 & $24 \%$ \\
\hline & 2-Low Default (less than 3 times/year) & 72 & $34 \%$ \\
\hline & 3-High Default (more than 3 times/year) & & \\
\hline & & 88 & $42 \%$ \\
\hline
\end{tabular}


Table 2. Correlation results among variables

\begin{tabular}{cccccccc}
\hline & $\begin{array}{c}\text { Family } \\
\text { Income }\end{array}$ & Employment & $\begin{array}{c}\text { Loan } \\
\text { Amount }\end{array}$ & Age & Gender & $\begin{array}{c}\text { Marital } \\
\text { Status }\end{array}$ & Education \\
\hline Loan Default & .112 & $-.211^{* * *}$ & $.143^{* *}$ & .108 & -.104 & .111 & $-.188^{* * *}$ \\
\hline Employment & $.158^{* *}$ & 1 & $.121^{*}$ & .114 & $-.127^{*}$ & .112 & .111 \\
\hline Loan Amount & $.124^{*}$ & $.121^{*}$ & 1 & $.131^{*}$ & -.103 & $.122^{*}$ & $.119^{*}$ \\
\hline Age & .108 & .114 & $.131^{*}$ & 1 & $-.121^{*}$ & .112 & .102 \\
\hline Gender & -.105 & $-.127^{*}$ & -.103 & $-.121^{*}$ & 1 & -.102 & .110 \\
\hline Marital Status & .112 & .113 & $.122^{*}$ & .112 & -.102 & 1 & $.131^{*}$ \\
\hline Education & $.125^{*}$ & .111 & $.119^{*}$ & .102 & .110 & $.131^{*}$ & 1 \\
\hline
\end{tabular}

Note: $* * *$ significant at $99 \%$;* significant at $95 \%$ and $*$ significant at $90 \%$

\subsection{Correlation Results Among Variables}

At 95\% confidence level, Pearson Correlation results show the relationship between pairs of variables. The results show that there are a negative and significant results between loan default with employment and education at -.211 and -.188; while a significant positive to loan amount at .143. This implies that higher default in study loan is mainly due to low family income and jobless issue. Higher engagement loan amount is significant to repayment default. Significant positive relationship between family income-employment at .158; family income-loan amount at .124; and family income-education at .125 were also recorded. Employment-loan amount at .121 has significant positive results while employment-gender shows significant negative at -.127. Loan amount-age shows significant positive at -.131; while loan amount-marital status at .122 and loan amount-education show positive at .119 and significant results. Age-gender is negative significant at -.121 while marital status-education is positive and significant at .131 .

\subsection{Multiple Regression Results Among Variables}

A regression analysis was performed to further examine the effect of study loan amount and the variables (family income, employment and loan amount) of study loan default while controlling the effect of respondents' demographic.

Table 3 depicts the results of the regression analysis. The results show that study loan default is significant to the factors of employment status and education (control variable) at $99 \%$ confidence level. Additionally, higher loan amount also confirms the significance relationship to factors of study loan default at $95 \%$ confidence level.

Thus, the results accepted the hypothesis of $\mathrm{H} 2$ and $\mathrm{H} 3$ while rejected H1.The results imply that the poorer respondents' employment status and higher amount of loan that the respondents engaged earlier are significant to be defaulted. Additionally, lower education level is also significant to the study loan default. Variance inflation factor (VIF) results show no multicollinearity problem suspected in this research parameter.

Table 3. Multiple Regression Results among the independent and control variables

\begin{tabular}{cccc} 
& Coefficients & T stat & VIF \\
\hline Loan Default & & & 1.105 \\
\hline Family Income & -.029 & -.411 & 1.118 \\
\hline Employment & -.167 & $-2.356^{* * *}$ & 1.167 \\
\hline Loan Amount & .158 & $2.128^{* *}$ & 1.278 \\
\hline Age & .057 & .824 & 1.088 \\
\hline Gender & .024 & .334 & 1.182 \\
\hline Marital Status & -.057 & -.800 & 1.165 \\
\hline Education & -.209 & $-2.857^{* * *}$ & 1.240 \\
\hline
\end{tabular}

Note: *** significant at $99 \% ; * *$ significant at $95 \%$ and $*$ significant at $90 \%$ 


\section{Conclusion}

The purpose of this study is to examine the effect of study loan borrowers' family income, employment status and loan amount to study loan default. The parameters of this study also control the effect of age, gender, marital status and education level.

The establishments of agencies that provide education loans as a source of financing for tertiary education have aided many students into pursuing higher education. Nonetheless, there is an alarming concern of the borrowers not paying back their student loan; hence, the process for students to repay the loans remains an unresolved issue. Therefore, this study was designed to gather information on the factors of study loan default with the effect of family income, employment status and loan amount while controlling the effect of respondents' demographic -age, gender, marital status and education level.

The results of the study show that only respondents' employment status, loan amount and education are significant to study loan default. The results of this study could pave way to researchers to further explore the reasons of default among graduates. The aspect of characteristics of borrowers should be among the concerns for future researchers.

\section{Acknowledgment}

This research was funded by Universiti Teknologi MARA, Johor, Malaysia under the GBest 2019 research grant.

\section{References}

Bakar, E. A., Masud, J., \& Jusoh, Z. M. (2006). Knowledge, attitude and perceptions of university students towards educational loans in Malaysia. Journal of Family and Economic Issues, 27(4), 692-701.

Gross, J. P., Cekic, O., Hossler, D., \& Hillman, N. (2010). What matters in student loan default: A review of the research literature. Journal of Student Financial Aid, 39(1), 2.

Hillman, N. W. (2015). Borrowing and Repaying Federal Student Loans. Journal of Student Financial Aid, 45(3).

Hoynes, H., Miller, D. L., \& Schaller, J. (2012). Who suffers during recessions?. Journal of Economic Perspectives, 26(3), 27-48.

Kofoed, M. S. (2017). To apply or not to apply: FAFSA completion and financial aid gaps. Research in Higher Education, 58(1), 1-39.

Li, Y., \& Chen, W. (2019). Entropy method of constructing a combined model for improving loan default prediction: A case study in China. Journal of the Operational Research Society, 1-11.

Lochner, L., \& Monge-Naranjo, A. (2004). Education and default incentives with government student loan programs. NBER Working Paper, 8815.

Martin, F., James, J., Andrew, R., Icek, A., \& Loken, B. (1980). Predicting and understanding family planning behaviors: beliefs, attitudes, and intentions. Understanding Attitudes and Predicting Social Behavior. Englewood Cliffs, NJ: Prentice-Hall.

McKinney, L., Gross, J. P. K., \& Inge, B. (2014). Understanding loan default among community college students. In meeting of the Association for the Study of Higher Education, Washington, DC.

McMillion, R. (2004). Student Loan Default Literature Review. TG (Texas Guaranteed Student Loan Corporation).

Qian, M., \& Hu, F. (2019). An Empirical Study on Prediction of the Default Risk on P2P Lending Platform. In IOP Conference Series: Materials Science and Engineering (Vol. 490, No. 6, p. 062048). IOP Publishing.

Redd, K. E. (2001). Why Do Students Borrow So Much? Recent National Trends in Student Loan Debt. ERIC Digest.

Steiner, M., \& Barone, S. (2014). Detecting early signs of default risk at Austin Community College.

Sugiyarti, E., Jasmi, K. A., Basiron, B., Huda, M., Shankar, K., \& Maseleno, A. (2018). Decision support system of scholarship grantee selection using data mining. International Journal of Pure and Applied Mathematics, 119(15), 2239-2249.

Wong, S. K. E., Nasharuddin, A., \& Ismail, K. (2015). Education loan repayment and performances: The Malaysian graduates perspectives. Jati-Journal of Southeast Asian Studies, 20, 158-172.

Woo, J. H. (2002). Factors affecting the probability of default: Student loans in California. Journal of Student Financial Aid, 32(2), 1.

Zainal, N. R., \& Ismail, N. (2017). Debt Composition of University Graduates and their Attitude towards Education Loan. Journal of ASIAN Behavioural Studies, 2(4), 41-47. 